\title{
Study of antimicrobial activities of chitinases from a potato prototype cultivated in Bangladesh
}

\author{
Syed Rashel Kabir ${ }^{* 1}$, Md. Azizul Haque ${ }^{1}$, Md. Nurujjaman ${ }^{1}$, Imtiaj Hasan ${ }^{1}$, Md. Abu Zubair ${ }^{4}$, Md. Robiul Hassan \\ Chowdhury ${ }^{1}$, Md. Belal Uddin ${ }^{1}$, Narayan Roy', Md. Kamrul Islam² and Nurul Absar ${ }^{183}$ \\ ${ }^{1}$ Department of Biochemistry and Molecular Biology, Faculty of Science, Rajshahi University, Rajshahi-6205, \\ Bangladesh. \\ ${ }^{2}$ Depatment of Physiology, Faculty of Veterinary Science, Bangladesh Agriculture University, Mymensingh-2202, \\ Bangladesh. \\ ${ }^{3}$ Department of Biochemistry and Biotechnology, University of Science and Technology, Chittagong (USTC), Foy's Lake, \\ Chittagong, Bangladesh. \\ ${ }^{4}$ Department of Food Technology and Nutritional Science, Mawlana Bhashani Science and Technology University, \\ Santosh, Tangail-1902, Bangladesh. \\ E-mail: rashelkabir@ru.ac.bd; rashelkabir@gmail.com
}

Received 7 June 2010; received in revised form 12 December 2010; accepted 30 December 2010

\begin{abstract}
Chitinases (designated as SPCs) were isolated from 'Shilbilati' potatoes, a potato prototype cultivated in Bangladesh by affinity chromatography on a chitin column. SPCs agglutinated rat erythrocytes at the minimum concentration of $7 \mu \mathrm{g} / \mathrm{mL}$ and showed toxicity against brine shrimp nauplii with the $\mathrm{LC}_{50}$ value of $20 \mu \mathrm{g} / \mathrm{mL}$. The chitinases also agglutinated seven bacterial strains among the twelve as studied. Pseudomonas aeruginosa, Bacillus subtilis and Salmonella typhi were the most sensitive towards the SPCs and were agglutinated at $1.2,2.5$ and $5.0 \mu \mathrm{g} / \mathrm{mL}$ protein concentrations respectively. Antibacterial tests demonstrated that SPCs showed inhibitory activity against the pathogenic bacteria Staphylococcus aureus, Bacillus subtilis and Salmonella typhi. Antifungal activity was investigated by the disc diffusion method. Five fungal species (Candida albicans, Aspergillus niger, Fusarium vasinfectum, Aspergillus fumigatus and Aspergillus flavus) and two fungal genus (Penicillium and Mucor sp.) were examined in the assay. SPCs showed antifungal activity against Candida albicans, Fusarium vasinfectum and Penicillium sp.
\end{abstract}

Keywords: lectins, antibacterial, antifungal, toxicity, hemagglutination

\section{INTRODUCTION}

Microorganisms are frequently a cause of prevailing diseases in developing countries. The economic crisis, inefficient public access to medical and pharmaceutical care, emergence of resistant strains, drug toxicity and the side-effects caused by synthetic drugs are some of the main factors influencing the search for the natural products having antimicrobial and antifungal activities.

For the past twenty years there has been an increased interest in the investigation of natural materials. Some of those have been approved as new antimicrobial drugs, but there is still an urgent need to identify novel substances that are active towards pathogens with high resistance (Recio, 1989; Cragg et al.,1997). Potato (Solanum tuberosum, Solanaceae), is the only major tuber crop that is grown in temperate regions. It is also the most important tuber crop in terms of production, accounting for about $45 \%$ of the total world production of all tuber crops (Shewry, 2003). Varieties of potatoes are cultivated worldwide and a number of chitin-binding proteins have been identified in potatoes (Solanum tuberosum L.) on the basis of their affinity, enzymatic properties or amino acid sequence (Allen and Neuberger, 1973; Desai and Allen, 1979; Kilpatrick, 1980; Matsumoto et al., 1980; Owens and Northcote, 1980; McCurrach and Kilpatrick, 1986; Millar et al., 1992; Pramod and Venkatesh, 2006). A major chitin binding component of potato is the lectin, which is a glycoprotein with an unusual amino acid composition characterized by a very high content (up to $30 \%$ ) of hydroxyproline (Van Damme et al., 2004).

Recent publications suggest that plant extracts may be used as microbicidal agents in vitro. A novel antimicrobial protein (AP1) was purified from leaves of the potato (Solanum tuberosum, variety MS-42.3) with a procedure involving ammonium sulphate fractionation, molecular sieve chromatography with Sephacryl S-200 and hydrophobic chromatography with Butyl-Sepharose using a FPLC system. The inhibition spectrum investigation showed that AP1 had good inhibition activities against five different strains of Ralstonia solanacearum from potato or other crops, and two fungal pathogens, Rhizoctonia solani and Alternaria solani from potato (Feng et al., 2003). The present study was undertaken to investigate the potential antimicrobial activity of the chitinases on a panel of microorganisms obtained from the potato prototype cultivated in Bangladesh. 


\section{MATERIALS AND METHODS}

\section{Isolation of lectins}

The edible portion of the potato prototype named 'Shilbilati' cultivated in the Rangpur region of Bangladesh was homogenized in $50 \mathrm{mM}$ Tris-HCl buffer $(\mathrm{pH} 8.0)$ containing $1 \% \mathrm{NaCl}$ and $0.02 \%$ sodium metabisulfite. The homogenate was centrifuged at $17,000 \mathrm{rpm}$ for $15 \mathrm{~min}$ and the supernatant was collected and subjected to affinity chromatography on a chitin column $(2 \times 25 \mathrm{~cm})$, previously equilibrated with $10 \mathrm{mM}$ Tris- $\mathrm{HCl}$ buffer, $\mathrm{pH}$ 8.0. The column was first washed by $10-15$ volume of 10 $\mathrm{mM}$ Tris- $\mathrm{HCl}$ buffer, $\mathrm{pH} 8.0$ and then followed by 2 volume of distilled water. Finally the proteins were eluted by $0.5 \mathrm{M}$ acetic acid. The eluted fraction was dialyzed against distilled water for overnight. Protein was estimated by the Lowry method using lipid-free BSA as the standard.

\section{Hemagglutination assay}

The hemagglutination assay was performed in 96-well microtiter U-bottomed plates in a final volume of $100 \mu \mathrm{L}$ containing $50 \mu \mathrm{L}$ of $2 \%$ suspension of albino rat erythrocytes previously washed with $0.15 \mathrm{M} \mathrm{NaCl}$ and 50 $\mu \mathrm{L}$ of two-fold serially diluted lectin solutions. After gentle shaking, the plate was kept at room temperature for 30 min; the agglutination titer of the maximum dilution giving positive agglutination was recorded.

\section{Brine shrimp nauplii lethality assay}

Toxicity of the proteins was studied using brine shrimp nauplii (Artemia salina L). Ten shrimps in artificial sea water $(\mathrm{pH} 7.0)$ were transferred to 50 vials and Shilbilati potato chitinases (SPCs) was added at the concentration of $0.005-0.5 \mathrm{mg} / \mathrm{mL}$. Finally the volume was adjusted to 3 $\mathrm{mL}$ by the addition of artificial sea water. All tests were performed at room temperature (around $30^{\circ} \mathrm{C}$ ), under a continuous light regime. Three replicates were used for each treatment and control. From these data, the percentage of mortality of the nauplii was calculated for each concentration and the $\mathrm{LC}_{50}$ values were determined using Probit analysis as described by Finney (1971).

\section{Bacterial agglutination activity}

The bacterial agglutinating activity was performed by Bacillus cereus, Staphylococcus aureus, Bacillus megaterium, Sarcina lutea, Pseudomonas aeruginosa, Shigella shiga, Shigella dysenteriae, Shigella sonnei, Salmonella typhi, and Klebsiella sp. Bacteria were grown in $37{ }^{\circ} \mathrm{C}$ overnight in nutrient broths (liquid nutrient medium) and collected by centrifugation at 4,000 rpm for 3 min, washed with $10 \mathrm{mM}$ Tris- $\mathrm{HCl}$ and re-suspended in the same buffer. $50 \mu \mathrm{L}$ of each bacterial suspension (2\%) was mixed with a serial dilution of partially purified protein solutions to a final volume of $100 \mu \mathrm{L}$ in 96 -well microtiter plate. The plate was agitated for $2 \mathrm{~min}$ and the mixture was kept at room temperature for $2 \mathrm{~h}$. Finally the bacterial agglutinating activity was monitored by a light microscope.

\section{Antibacterial assay}

Antibacterial activity of the chitin binding proteins was investigated by the disc diffusion method (Cole, 1994), performed using sterile-petri dishes $(100 \times 15 \mathrm{~mm})$ containing $30 \mathrm{~mL}$ nutrient agar. Twelve species of pathogenic bacteria were seeded separately onto the surface of nutrient agar plates, followed by the placement of a sterile double filter paper disc ( $5 \mathrm{~mm}$ diameter) on the agar surface of each plate. An aliquot $(10 \mu \mathrm{L})$ of each sample was then added to each disc and the bacterial cells were allowed to grow at $30{ }^{\circ} \mathrm{C}$ for $12 \mathrm{~h}$. A transparent ring around the paper disc revealed the antimicrobial activity. Eleven bacterial species (Bacillus cereus, Staphylococcus aureus, Bacillus subtilis, Bacillus megaterium, Sarcina lutea, Pseudomonas aeruginosa, E. coli, Shigella shiga, Shigella dysenteriae, Shigella sonnei, Salmonella typhi) and one bacterial genus Klebsiella sp. were examined in the assay.

\section{Antifungal assay}

Antifungal activities of the chitin binding lectins were performed using sterile-petri dishes $(100 \times 15 \mathrm{~mm})$ containing $30 \mathrm{~mL}$ potato dextrose agar. Fungal mycelia were placed over the solid potato dextrose agar and the sterile filter paper discs (5 $\mathrm{mm}$ in diameter) were distributed over the plate. Protein solutions at different concentration in Tris- $\mathrm{HCl}$ buffer $(\mathrm{pH} \mathrm{7.8)}$ containing 0.15 $\mathrm{M} \mathrm{NaCl}$ (TBS) and the TBS as the control, were applied on each paper disc of Petri dishes. Incubation of the Petri dishes were carried out at $31^{\circ} \mathrm{C}$ until mycelial growth had enveloped discs containing the control and formed crescents of inhibition around the discs with antifungal samples. Five fungal species (Candida albicans, Aspergillus niger, Fusarium vasinfectum, Aspergillus fumigatus and Aspergillus flavus) and two fungal genus (Penicillium and Mucor sp.) were examined in the assay.

\section{RESULTS AND DISCUSSION}

\section{Hemagglutination assay}

SPCs were isolated from a variety of potatoes named Shilbilati, by using single step affinity chromatography on chitin column. The unbound fractions did not show any agglutination activity whereas the bound fraction (designated as SPCs) showed high agglutination activity against the albino rat erythrocytes with the minimum concentration of $7.0 \mu \mathrm{g} / \mathrm{mL}$. The proteins might be included in the category of lectin as they agglutinated rat erythrocytes.

\section{Brine shrimp nauplii lethality assay}

Some lectins are toxic and showed toxicity against brine shrimp nauplii. Our present data showed the mortality rate of brine shrimp nauplii raised with the increase of the 
concentration of the lectin. In the present study $50 \%$ mortality of the nauplii occurs $\left(\mathrm{LC}_{50}\right)$ at $20 \mu \mathrm{g} / \mathrm{mL}$ concentration of SPCs (Figure 1), where as $\mathrm{LC}_{50}$ of MSL (mannose specific lectin) was $21.87 \mu \mathrm{g} / \mathrm{mL}$ (Absar et al., 2005). This result revealed that SPCs toxicity is similar to the MSL.

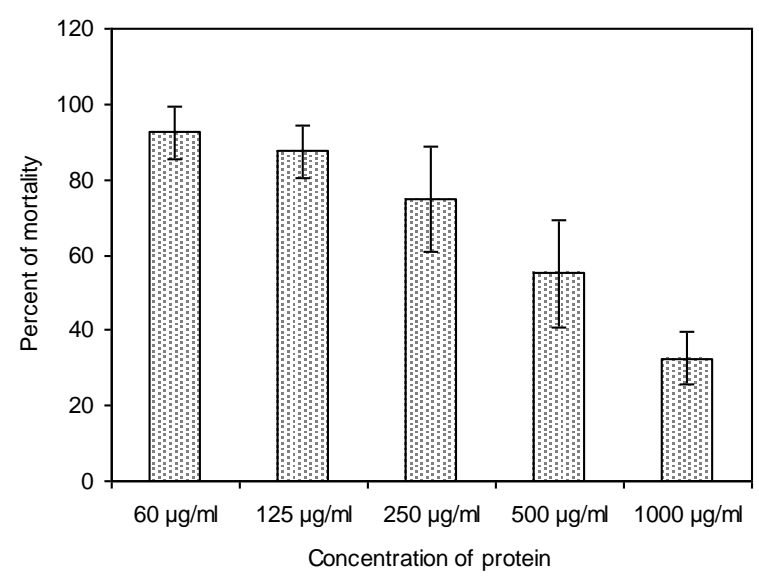

Figure 1: Percent of mortality of brine shrimp nauplii treated with SPCs solution after exposure for $24 \mathrm{~h}$.

\section{Bacterial agglutination activity}

SPCs agglutinated both gram positive and gram negative bacteria (Staphylococcus aureus, Pseudomonas aeruginosa, Klebsiella sp., Shigella shiga, Shigella dysenteriae, Shigella sonnei and Salmonella typhi) as presented in Table 1.

It was reported that EuniS lectin agglutinated Bacillus cereus, Staphylococcus sp., Bacillus subtilis, Pseudomonas aeruginosa and E. coli (Oliveira et al., 2008). The bacterial agglutination might be due to the presence of cognate glycan antigen on the cell surface of induced bacteria. The inhibition study suggested that the bacterial agglutination occurred as a result of the interaction of lectins with bacterial surface carbohydrates (Ghanekar and Pérombelon, 1980). The result showed that Pseudomonas aeruginosa, Shigella dysenteriae, Salmonella typhi and Klebsiella sp. were most sensitive towards SPCs and the minimum agglutination concentration were 1.2, 2.5, 5.0 and $10.0 \mu \mathrm{g} / \mathrm{mL}$ respectively. Agglutination of several bacterial strains confirms the interaction between the lectins and the strains.

\section{Antibacterial assay}

SPCs exhibited antibacterial activity against the tested pathogenic bacteria Pseudomonas aeruginosa, Bacillus subtilis and Salmonella typhi. The antibacterial activity of the SPCs against Salmonella typhi is shown in Figure 2. A zone of inhibition is formed at a concentration of 4.0 $\mathrm{mg} / \mathrm{mL}$ that gives higher inhibition than the zones formed at concentrations of 2.0 and $0.5 \mathrm{mg} / \mathrm{mL}$ of SPCs. So it is clear that the inhibitory zone became larger with the increase of concentrations of SPCs. Figure 2 also represents the antibacterial activity of SPCs against Bacillus subtilis. SPCs showed visible inhibitory zone at the concentration of $1.5 \mathrm{mg} / \mathrm{mL}$. When the applied concentration was twofold of the previous one then the inhibitory zone increased remarkably. The antibacterial activity of SPCs against Staphylococcus aureus represented a different result from those of the above. It showed higher activity at a low concentration $(1.5 \mathrm{mg} / \mathrm{mL})$ as compared to that as observed at $3.0 \mathrm{mg} / \mathrm{mL}$.

Table 1: Minimum concentrations of Shilbilati potato chitinases (SPCs) needed for visible agglutination of some pathogenic bacteria.

\begin{tabular}{ll}
\hline Bacterium & $\begin{array}{l}\text { SPCs } \\
(\mu \mathrm{g} / \mathrm{mL})\end{array}$ \\
\hline Bacillus cereus & - \\
Staphylococcus aureus & 86 \\
Bacillus subtilis & - \\
Bacillus megaterium & - \\
Sarcina lutea & - \\
Pseudomonas aeruginosa & 1.2 \\
Klebsiella species & 10 \\
Escherichia coli & - \\
Shigella shiga & 86 \\
Shigella dysenteriae & 2.5 \\
Shigella sonnei & 43 \\
Salmonella typhi & 5 \\
\hline
\end{tabular}

In recent years, it was reported that various plant extracts showed high antimicrobial activity (Sağdıç et al., 2002). Lectins in higher plants defend against pathogenic bacteria and fungi by recognizing the infecting microorganisms via binding; thereby preventing their subsequent growth and multiplication (Etzler, 1986). It was reported that heat-stable serine protease inhibitor from the potato tuber inhibited the growth of a variety of bacterial strains, Straphylococcus aureus and E. coli (Kim, 2006); and EuniS lectin showed inhibitory activity against Staphylococcus sp., Bacillus subtilis, E. coli and Pseudomonas aeruginosa (Oliveira et al., 2008).

\section{Antifungal assay}

SPCs showed antifungal activity against three fungi among the seven as studied. The inhibitory activity of the protein solution against Candida albicans on PDA was presented in Figure 3. A zone of inhibition is formed at a concentration of $2.5 \mathrm{mg} / \mathrm{mL}$ whereas in case of Fusarium vasinfectum and Penicillium sp. antifungal activities were found at a lower concentration of $1.5 \mathrm{mg} / \mathrm{mL}$.

Chitin-binding lectins have been isolated from different sources; including bacteria, insects, plants and mammals (Campos-Olivas et al., 2001; Rebers and Willis, 2001; Suzuki et al., 2002; Van Dellen et al., 2002) and 


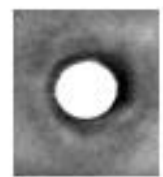

0.5

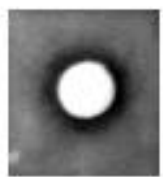

2.0

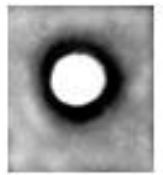

4.0

Salmonella typhi

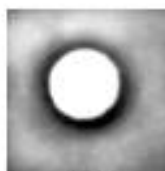

1.5

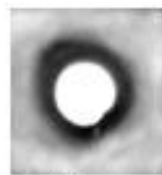

3.0

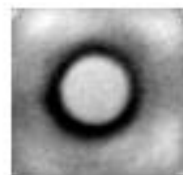

1.5

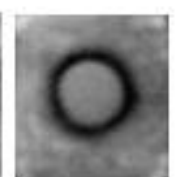

3.0

Bacillus subtilis

Figure 2: Antibacterial activities of SPCs towards Salmonella typhi, Bacillus subtilis and Staphylococcus aureus at different protein concentrations $(0.5-4.0 \mathrm{mg} / \mathrm{mL})$.

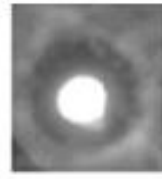

2.5

Candida albicans

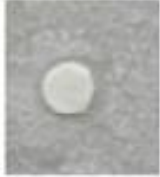

1.5

Fusarium vasinfectum

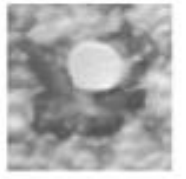

1.5

Penicillium sp.

Figure 3: Antifungal activities of SPCs towards Candida albicans, Fusarium vasinfectum and Penicillium sp. at different protein concentrations ( 1.5 and $2.5 \mathrm{mg} / \mathrm{mL}$ ).

most of them have shown the antifungal activity. It was reported that Stinging nettle rhizomes lectin, Klaxveromyces bulgaricus lectin, a lectin-like protein from Amaranthus caudatus and a chitinase-like lectin from Urtica diocia possessed the anti-fungal activities (Broekaert et al., 1989; Verheyden et al., 1995). SPCs showed noticeable activities against Candida albicans, Aspergillus fumigatus and Penicillium sp. The anti-fungal activities of SPCs showed good correlation with the activities of chitinases studied previously (Broekaert et al., 1989; Verheyden et al., 1995; Campos-Olivas et al., 2001; Rebers and Willis, 2001; Suzuki et al., 2002; Van Dellen et al., 2002). From the above study it is obvious that Shilbilati potato chitinases (SPCs) possessed antimicrobial activities.

\section{CONCLUSIONS}

In summary, a mixture of chitinases named as SPCs were isolated from the Shilbilati potato prototype. It possessed marked antimicrobial activity towards several bacterial and fungal species that is remarkable and hopefully it can be developed into an antimicrobial agent for the treatment of infectious diseases. Further studies might lead to the purification of novel lectins from this source and can be regarded as a more potent antimicrobial agent.

\section{REFERENCES}

Absar, N., Yeasmin, T., Raza, M. S., Sarkar, S. K. and Arisaka, F. (2005). Single step purification, characterization and $\mathrm{N}$-terminal sequences of a mannose specific lectin from mulberry seeds. The Protein Journal 24, 369-377.

Allen, A. K. and Neuberger, A. (1973). The purification and properties of the lectin from potato tubers, a hydroxyproline-containing glycoprotein. Biochemical Journal 135, 307-314.

Broekaert, W. F., Van P. J., Leyns F., Joos H. and Peumans W.J. (1989). A chitin-binding lectin from stinging nettle rhizomes with antifungal properties. Science 245, 1100-1102.

Campos-Olivas, R., Hörr, I., Bormann, C., Jung, B. and Gronenborn, A. M. (2001). Solution structure, backbone dynamics and chitin-binding of the antifungal protein from Streptomyces tendae TÜ901. Journal of Molecular Biology 308, 765-782.

Cole, M.D. (1994). Key antifungal, antibacterial and antiinsect assays - A critical review. Biochemical Systamatics and Ecology 22, 837-856.

Cragg, G.M., Newman, D.J. and Snader, K.M., (1997). Natural products in drug discovery and development. Journal of Natural Products 60, 52-60.

Millar, D.J., Allen, A.K, Smith, C.G., Sidebottom, C, Slabas A.R., and Bolwell, G. P. (1992). Chitinbinding proteins in potato (Solanum tuberosum L.) tuber characterization, immunolocalization and effects of wounding. Biochemical Journal 283, 813-821.

Desai, N. N., Allen and A. K. (1979). The purification of potato lectin by affinity chromatography on an $N, N$, $\mathrm{N}$-triacetyl chitotriose-Sepharose matrix. Analytical Biochemistry 93, 88-90.

Etzler M. E., (1986). Distribution and function of plant lectins. In: Liener IE, Sharon N, Goldstein IJ (eds), 
The lectins. Properties, function, and applications in biology and medicine. Academic, Orlando, Florida. p. 371-435.

Finney, D.J. (1971). Probit analysis. PP.333. Cambridge University press, London.

Ghanekar A. and Pérombelon M. C. M. (1980). Interactions between potato lectin and some phytobacteria in relation to potato tuber decay caused by Erwinia carotovora. Journal of Phytopatho 98, 137-149.

Feng, J., Yuan, F., Gao, Y., Liang, C., Xu, J., Zhang, C. and He, L. (2003). A novel antimicrobial protein isolated from potato (Solanum tuberosum) shares homology with an acid phosphatase. Biochemical Journal 376, 481-487.

Kilpatrick, D. C. (1980). Isolation of a lectin from the pericarp of potato (Solanum tuberosum) fruits. Biochemical Journal 191, 273-275.

Kim M. H. (2006). Purification and characterization of a heat-stable serine protease inhibitor from the tubers of new potato variety "Golden Valley". BBRC. 346, 681-686.

Lowry, O. H., Rosebrough, N. J., Farr, A. L. and Randall, R. J. (1951). J. Biol. Chem., 193, 265-275.

Matsumoto, I., Jimbo, A., Mizuno, Y., and Sen, N. (1983). Purification and characterization of potato lectin. The Journal of Biological Chemistry 258, 28862891.

McCurrach, P. M., Kilpatrick, D. C. (1986). Purification of potato lectin (Solanum tuberosum agglutinin) from tubers or fruits using chromatofocussing. Analytical Biochemistry 154, 492-496.

Oliveira, M. D. L., Andrade, C. A. S., Santos-Magalha, N. S., Coelho, L. C. B. B., Teixeira, J. A. Carneiroda-Cunha, M. G. and Correia, M. T. S. (2008). Purification of a lectin from Eugenia uniflora L. seeds and its potential antibacterial activity. Letters in Applied Microbiology 46, 371-376.

Owens, R.J. and Northcote, D.H. (1980). The purification of potato lectin by affinity chromatography on a fetuinSepharose matrix. Phytochemistry 19, 1861-72.

Rebers, J. E. and Willis, J. H. (2001). A conserved domain in arthropod cuticular proteins binds chitin. Insect Biochemistry and Molecular Biology 31, 10831093.

Recio, M.C. (1989). A review of some antimicrobial compounds isolated from medicinal plants reported in the literature 1978-1988. Phytotherapy Research 3, 1445-1453.

Sağdıç, O., Kuşçu, A., Özcan, M., Özçelik, S. (2002). Effects of Turkish spice extracts at various concentrations on the growth of Escherichia coli 0157:H7. Food Microbiology 19, 473-480.

Shewry, P. R., (2003). Tuber storage proteins. Annals of Botany 91, 755-769.

Pramod, S. N. and Venkatesh V. (2006). Utility of pentose colorimetric assay for the purification of potato lectin, an arabinose-rich glycoprotein. Glycoconjugate Journal 23, 481-488.
Suzuki, M., Morimatsu, M. and Syuto, B. (2002). The identification and properties of chitin-binding protein b01 (CBPb01). Journal of Veterinary Medical Science 64, 477-481.

Van Damme, E. J. M., Barre, A., Rouge P. and Peumans, W. J. (2004). Potato lectin: An updated model of a unique chimeric plant protein. The Plant Journal 37, 34-45.

Van Dellen, K., Ghosh, S. K., Robbins, P. W., Loftus, B. and Samuelson, J. (2002). Entamoeba histolytica lectins contain unique 6-Cys or 8-Cys chitin-binding domains. Infection and Immunuty 70, 3259-3263.

Verheyden, P., Pletinckx, J., Maes, D., Pepermans, H. A., Wyns, L., Willem, R. and Martins, J. C. (1995). $1 \mathrm{H}$ NMR study of the interaction of $\mathrm{N}, \mathrm{N}$ ',N"-triacetyl chitotriose with Ac-AMP2, a sugar binding antimicrobial protein isolated from Amaranthus caudatus. FEBS Letters 370, 245-249. 